\title{
DOSIS OPTIMUM LARUTAN KAPUR UNTUK NETRALISASI pH AIR LIMBAH PENAMBANGAN BATUBARA
}

\author{
Ahmad Faisal ${ }^{1}$, Syarifudin A. ${ }^{2}$ \\ Poltekkes Kemenkes Banjarmasin Jurusan Kesehatan Lingkungan Banjarbaru \\ Jl. H. Mistar Cokrokusumo No. 1A Kota Banjarbaru \\ 1 faisal@yahoo.co.id dan ${ }^{2}$ syarif_yazid@yahoo.com
}

\begin{abstract}
Abstrak: Dosis Optimum Larutan Kapur Untuk Netralisasi pH Air Limbah Penambangan Batubara. Penambangan batubara menyebabkan terlepasnya senyawa kimia seperti pirit $\left(\mathrm{Fe}_{2} \mathrm{~S}\right)$, menghasilkan air limbah buangan bersifat asam $\left(\mathrm{H}_{2} \mathrm{SO}_{4}\right)$. Penelitian ini bertujuan untuk mengetahui dosis optimum larutan kapur dalam menetralisasi $\mathrm{pH}$ air limbah penambangan batubara. Jenis penelitian ini adalah eksperimental dengan rancangan pretestpostest with control group design, mengukur $\mathrm{pH}$ sebelum perlakuan dan mengukur $\mathrm{pH}$ sesudah perlakuan. Pengambilan sampel air limbah penambangan dengan teknik composite sampling. Hasil penelitian nilai rata-rata $\mathrm{pH}$ air limbah penambangan batubara sebelum penambahan larutan kapur $2 \%$ adalah 4,9 , sedangkan air limbah dengan penambahan variasi dosis larutan kapur mengalami perubahan $\mathrm{pH}$, dengan dosis $1 \mathrm{ml} \mathrm{pH-nya} \mathrm{adalah} \mathrm{5,3,}$ dosis $3 \mathrm{ml} \mathrm{pH-nya} \mathrm{adalah} \mathrm{7,1,} \mathrm{dosis} 5 \mathrm{ml} \mathrm{pH}$-nya adalah 8,2, dosis $7 \mathrm{ml} \mathrm{pH}$-nya adalah 9,7 dan dosis $9 \mathrm{ml} \mathrm{pH-nya} \mathrm{adalah} \mathrm{10,5.} \mathrm{Hasil} \mathrm{uji} \mathrm{statistik} \mathrm{menggunakan} \mathrm{uji} \mathrm{One} \mathrm{Way} \mathrm{Anova} \mathrm{diperoleh}$ nilainya adalah 0,000 , nilai ini lebih kecil dari $\alpha=0,05$, ada beda antara rata-rata $\mathrm{pH}$ air limbah penambangan batubara pada berbagai penambahan variasi dosis larutan kapur $2 \%$. Hasil Uji Regresi linier didapatkan persamaan linier $y=4,906+0,649 x$ dengan kekuatan hubungan (R) sebesar 0,982. Dosis optimum larutan kapur dalam menetralisasi $\mathrm{pH}$ air limbah penambangan adalah $3,23 \mathrm{~mL}$ larutan kapur $2 \%$ dalam 1 liter air limbah penambangan batubara, $\mathrm{pH}=7$.
\end{abstract}

Kata Kunci : Air limbah batubara; larutan kapur; pH.

\begin{abstract}
Abstrak: Optimum Dose of Hydrated Lime for pH Neutralizing in Coal Mine Wastewater. Coal mines release chemicals such as pyrite $\left(\mathrm{Fe}_{2} \mathrm{~S}\right)$, produce acid waste water $\left(\mathrm{H}_{2} \mathrm{SO}_{4}\right)$. This research aims to know the optimum dose of hydrated lime to neutralize the $\mathrm{pH}$ of coal mining wastewater. This research was experimental study with pretest-postest with control group design, measured $\mathrm{pH}$ before and after treatment. Coal mines wastewater was sampled with composite sampling method. The result showed that the average of wastewater's $\mathrm{pH}$ before added $2 \%$ hydrated lime were 4,9 , while wastewater added by variated dose of hydrated lime, the $\mathrm{pH}$ changed. Added 1, 3, 5, 7 and $9 \mathrm{ml}$ hydrated lime, the $\mathrm{pH}$ particularly to be 5,3, 7,1, 8,2, 9,7 and 10,5. Statistical test using One Way Anova showed the $\mathrm{p}$ value $=0,000$, ore less than $\alpha=0,05$. There was the difference significantly between $\mathrm{pH}$ 's average of coal mine wastewater at variation in dose of $2 \%$ hydrated lime. Test of Linier regression found equation; $y=4,906+0,649 x$ with correlation value $(R)=0,982$. Optimum dose of $2 \%$ hydrated lime for $\mathrm{pH}$ neutralizing 1 litre of coal mine wastewater was 3,23, $\mathrm{pH}=7$.
\end{abstract}

\section{PENDAHULUAN}

Indonesia adalah negara yang kaya dengan sumber daya alam, salah satunya adalah batubara. Cadangan batubaranya yang besar membuat negeri ini sebagai produsen sekaligus eksportir utama batubara di dunia. ${ }^{1}$ Berdasarkan data terakhir dari Statistik Batubara Indonesia perkiraan cadangan batubara Indonesia adalah 104,940 miliar ton.

Simpanan batubara terbesar di Indonesia terdapat di Kalimantan (52,6\%) dan Sumatera (46,8\%), selebihnya terdapat di Jawa, Sulawesi, Maluku dan Papua. Sebagian besar cadangan batubara negeri ini tersebar hanya di tiga provinsi, yaitu Sumatera Selatan (39\%), Kalimantan Timur (34\%) dan Kalimantan Selatan (16\%). Ketiga provinsi ini menguasai 89\% dari semua cadangan batubara terukur di Indonesia. $^{2}$

Penambangan batubara menyebabkan terlepasnya unsur-unsur kimia tertentu seperti Fe dan S dari senyawa pirit 
$\left(\mathrm{Fe}_{2} \mathrm{~S}\right)$, dan hasil reaksi antara air dengan senyawa tersebut akan menghasilkan air buangan bersifat asam (Acid Mine Drainage/Acid Rock Drainage).

Air buangan tersebut mengalir ke badan air sungai yang juga diakses masyarakat sekitar, serta air buangan dapat hanyut terbawa aliran permukaan pada saat hujan dan masuk ke lahan pertanian di bagian hilir pertambangan, sehingga menyebabkan keasaman tanahnya lebih tinggi. Tanah dan air asam tambang tersebut sangat asam dengan $\mathrm{pH}$ berkisar antara 2,5-5 yang berpotensi mencemari badan air dan lahan pertanian. ${ }^{3}$

Kegiatan industri (pertambangan batubara) berdampak negatif terhadap sumber daya air, antara lain menyebabkan penurunan kualitas air. Kondisi ini dapat menimbulkan gangguan, kerusakan, dan bahaya bagi semua makhluk hidup yang bergantung pada sumber daya air tersebut. Oleh karena itu, diperlukan pengelolaan dan perlindungan sumber daya air secara seksama. ${ }^{4}$

Total produksi batubara di Provinsi Kalimantan Selatan dari tahun 2006-2011 yaitu sekitar 474,893 juta ton. ${ }^{5}$ Kebanyakan perusahaan pertambangan batubara, pengolahan air limbahnya hanya diolah dengan metode sederhana yaitu dengan menggunakan kolam pengendapan (settling pond). Dengan cara ini pengolahan air limbah penambangan batubara kurang efektif khususnya dari segi parameter $\mathrm{pH}$ (derajat keasaman).

Air limbah penambangan batubara yang pH-nya rendah mengalir ke sungai akan mempengaruhi $\mathrm{pH}$ air sungai, menyebabkan masyarakat yang sehari-hari menggunakan air sungai tersebut mengeluh, antara lain keluhan masyarakat yaitu airnya berasa "masam", pemborosan sabun (karena busa sabun sangat sulit dihasilkan pada air yang bersifat asam), ikan dan tumbuhan di sekitar sungai banyak yang mati dan alat-alat rumah tangga yang mengandung logam dan besi cepat berkarat, sehingga dari hal tersebut diperlukan metode netralisasi menggunakan larutan kapur yang ditambahkan ke dalam air limbah penambangan batubara. Kapur selain mudah didapat dan murah, juga dapat dilarutkan dalam air dan men- jadi kalsium hidroksida $\left(\mathrm{Ca}(\mathrm{OH})_{2}\right)$, larutan $\mathrm{Ca}(\mathrm{OH})_{2}$ disebut air kapur dan merupakan basa dengan kekuatan sedang. Larutan tersebut bereaksi hebat dengan berbagai asam. ${ }^{6}$ Larutan dengan sifat basa tersebut akan menetralisasi $\mathrm{pH}$ air limbah penambangan batubara dan diharapkan dengan dosis kapur yang optimum didapatkan $\mathrm{pH}$ air limbah penambangan batubara yang memenuhi persyaratan, yaitu antara 6-9.

\section{METODE}

Jenis penelitian ini adalah eksperimental dengan rancangan pretes-postes dengan kelompok kontrol (pretest-postest with control group design), yaitu dengan mengukur $\mathrm{pH}$ sebelum perlakuan (pretes) dan mengukur $\mathrm{pH}$ sesudah perlakuan (postes). Perlakuannya yaitu dengan menetralisasi $\mathrm{pH}$ air limbah penambangan batubara dengan penambahan beberapa dosis larutan kapur $\left(\mathrm{Ca}(\mathrm{OH})_{2} 2 \%\right)$. Kemudian ada air limbah yang tidak dilakukan perlakuan (kontrol).

Bahan-bahan yang digunakan dalam penelitian ini adalah larutan kapur $\left(\mathrm{Ca}(\mathrm{OH})_{2} 2 \%\right)$ dan air limbah tambang batubara, sedangkan instrumen penelitian meliputi drum plastik $120 \mathrm{ml}$ dan stopwatch untuk pengukuran debit air limbah, jerigen 20 liter dan jerigen 2 liter untuk pengambilan sampel air limbah, $\mathrm{pH}$ meter, dan seperangkat alat pemeriksaan laboratorium seperti beaker glass $(250 \mathrm{ml}$ dan $1.000 \mathrm{ml}$ ), sendok, neraca analitik, flokulator, kaca arloji dan pipet $10 \mathrm{ml}$.

Prosedur penelitian meliputi observasi pendahuluan, pengukuran debit air limbah penambangan batubara, pengambilan sampel air limbah penambangan batubara, persiapan alat, bahan dan tempat untuk perlakuan percobaan dan pembuatan larutan kapur (ca(oh) 2 2\%). Percobaan meliputi tahap-tahap berikut:

1. Menyiapkan 6 buah beaker glass 1.000 $\mathrm{ml}$, setelah itu memberi label pada wadah sesuai dengan variasi dosis yang ingin dicoba (0 $\mathrm{ml}$ (kontrol), 1 $\mathrm{ml}, 3 \mathrm{ml}, 5 \mathrm{ml}, 7 \mathrm{ml}$ dan $9 \mathrm{ml}$ ).

2. Mengambil sampel air limbah dan memasukkan sampel ke dalam 6 buah beaker glass $1.000 \mathrm{ml}$, masing-masing sebanyak 1 liter dan salah satu sebagai kontrol. 
3. Memasukkan larutan kapur $2 \%$ ke dalam 6 buah beaker glass $1.000 \mathrm{ml}$ dengan masing-masing dosis $0 \mathrm{ml}$ (kontrol), $1 \mathrm{ml}, 3 \mathrm{ml}, 5 \mathrm{ml}, 7 \mathrm{ml}$ dan 9 $\mathrm{ml}$ dalam $1.000 \mathrm{ml}$ air limbah.

4. Mengaduk air limbah penambangan batubara yang sudah ditambahkan larutan kapur 2\% selama 2-3 menit.

5. Mengukur dan mencatat perubahan $\mathrm{pH}$ berdasarkan penambahan variasi dosis larutan kapur $2 \%$.
6. Melakukan pengulangan pada setiap tahapan untuk uji ke 2 dan ke 3.

\section{HASIL DAN PEMBAHASAN}

Hasil perlakuan dengan menambahkan berbagai variasi dosis larutan kapur $\left(\mathrm{Ca}(\mathrm{OH})_{2} 2 \%\right)$ pada air limbah penambangan batubara, didapatkan hasil ratarata perubahan $\mathrm{pH}$ air limbah sebagai berikut:

Tabel.1 Rata-Rata Perubahan pH Air Limbah Penambangan Batubara pada Berbagai Penambahan Variasi Dosis Larutan Kapur $\left(\mathrm{Ca}(\mathrm{OH})_{2} 2 \%\right)$

\begin{tabular}{cccccc}
\hline No & $\begin{array}{c}\text { Variasi Dosis } \\
\text { Larutan Kapur } \\
\left(\mathrm{Ca}(\mathrm{OH})_{2} 2 \%\right)\end{array}$ & \multicolumn{3}{c}{ Perubahan $\mathrm{pH}$ Air Limbah } & \multirow{2}{*}{$\begin{array}{c}\text { Rata-Rata Perubahan } \mathrm{pH} \\
\text { Air Limbah }\end{array}$} \\
\cline { 2 - 5 } & $0 \mathrm{ml}$ & 4,8 & 5,0 & 4,8 & 4,9 \\
\hline 1 & $1 \mathrm{ml}$ & 5,3 & 5,3 & 5,3 & 5,3 \\
2 & $3 \mathrm{ml}$ & 7,2 & 6,8 & 7,2 & 7,1 \\
3 & $5 \mathrm{ml}$ & 8,5 & 8,0 & 8,2 & 8,2 \\
4 & $7 \mathrm{ml}$ & 9,7 & 9,7 & 9,7 & 9,7 \\
5 & $9 \mathrm{ml}$ & 10,3 & 10,7 & 10,5 & 10,5 \\
6 & & &
\end{tabular}

Sumber: Hasil uji laboratorium kimia Jurusan Kesehatan Lingkungan Politeknik Kesehatan Banjarmasin

Tabel 1 di atas menunjukkan bahwa nilai rata-rata $\mathrm{pH}$ air limbah penambangan batubara awal (tidak ditambahkan larutan kapur 2\%) adalah 4,9, sedangkan air limbah yang diberi berbagai penambahan variasi dosis larutan kapur $\left(\mathrm{Ca}(\mathrm{OH})_{2} 2 \%\right)$ mengalami perubahan $\mathrm{pH}$, yaitu dengan dosis $1 \mathrm{ml} \mathrm{pH}=5,3$, dosis 3 $\mathrm{ml} \mathrm{pH}=7,1$, dosis $5 \mathrm{ml} \mathrm{pH}=8,2$, dosis 7 $\mathrm{ml} \mathrm{pH}=9,7$ dan dosis $9 \mathrm{ml} \mathrm{pH}=10,5$.

\section{Hasil Pengujian Data}

Pengujian data menggunakan uji statistik, yaitu dengan uji One Way Anova (uji beda), uji Korelasi (uji hubungan) dan uji Regresi linier (prediksi dosis optimum)

1. Perbedaan rata-rata $\mathrm{pH}$ air limbah pada berbagai penambahan variasi dosis larutan kapur $\left(\mathrm{Ca}(\mathrm{OH})_{2} 2 \%\right)$

Hasil pengujian data untuk mengetahui apakah ada perbedaan perubahan rata-rata $\mathrm{pH}$ air limbah yang signifikan pada berbagai penambahan variasi dosis larutan kapur $\left(\mathrm{Ca}(\mathrm{OH})_{2} 2 \%\right)$ yang dilakukan dengan uji One Way Anova. Hasil uji diperoleh nilainya adalah 0,000 , nilai ini lebih kecil dari $\alpha=0,05$, sehingga dapat disimpulkan bahwa ada beda antara rata- rata $\mathrm{pH}$ air limbah penambangan batubara pada berbagai penambahan variasi dosis larutan kapur $\left(\mathrm{Ca}(\mathrm{OH})_{2} 2 \%\right)$.

Untuk mengetahui perbedaan perubahan rata-rata $\mathrm{pH}$ air limbah pada penambahan variasi dosis larutan kapur $\left(\mathrm{Ca}(\mathrm{OH})_{2} 2 \%\right)$, maka dilakukan Post Hoc Tests dengan uji LSD (Least Significant Difference). Hasil semua nilai kemaknaannya lebih kecil dari $\alpha=0,05$, artinya ada perbedaan yang bermakna antara ratarata $\mathrm{pH}$ air limbah dengan masing-masing penambahan variasi dosis larutan kapur $2 \%$. Penambahan variasi dosis larutan kapur $\left(\mathrm{Ca}(\mathrm{OH})_{2} 2 \%\right)$ yaitu dosis $0 \mathrm{ml}, 1$ $\mathrm{ml}, 3 \mathrm{ml}, 5 \mathrm{ml}, 7 \mathrm{ml}$ dan $9 \mathrm{ml}$. Hubungan perubahan rata-rata $\mathrm{pH}$ air limbah pada berbagai penambahan variasi dosis larutan kapur $\left(\mathrm{Ca}(\mathrm{OH})_{2} 2 \%\right)$

Hasil pengujian data untuk mengetahui apakah ada hubungan perubahan rata-rata $\mathrm{pH}$ air limbah yang signifikan pada berbagai penambahan variasi dosis larutan kapur $\left(\mathrm{Ca}(\mathrm{OH})_{2} 2 \%\right)$ yang dilakukan dengan uji Korelasi, nilai dari Sig. (2tailed), nilainya ad`alah 0,000 lebih kecil dari $\alpha=0,05$, sehingga dapat dikatakan 
bahwa ada hubungan antara rata-rata $\mathrm{pH}$ air limbah penambangan batubara pada berbagai penambahan variasi dosis larutan kapur $\left(\mathrm{Ca}(\mathrm{OH})_{2} 2 \%\right)$. Karena ada hubungan, maka dapat dilanjutkan dengan uji Regresi linier untuk mendapatkan model persamaan linier.

2. Prediksi dosis optimum larutan kapur $\left(\mathrm{Ca}(\mathrm{OH})_{2} 2 \%\right)$

Hasil pengujian data untuk memprediksi dosis optimum larutan kapur $\left(\mathrm{Ca}(\mathrm{OH})_{2} 2 \%\right)$ untuk menetralisasi $\mathrm{pH}$ air limbah penambangan batubara yang dilakukan dengan uji Regresi linier. Hasil uji diketahui persamaan linier yang didapatkan yaitu $\mathrm{y}=4,906+0,649 \mathrm{x}$ dengan kekuatan hubungan (R) sebesar 0,982. Konstanta sebesar 4,906 menyatakan bahwa jika tidak dilakukan penambahan dosis larutan kapur 2\%, maka pH air limbah adalah 4,906. Sedangakan koefisien regresi sebesar 0,649 menyatakan bahwa setiap penambahan $1 \mathrm{ml}$ larutan kapur $2 \%$ pada 1 liter air limbah akan menaikkan pH air limbah sebesar 0,649.
Kemudian, untuk mengetahui kualitas persamaan regresi linier tersebut dapat dilihat dari nilai kekuatan hubungan (R) dan uji ANOVA dari Regresi linier tersebut. Nilai kekuatan hubungan (R), diketahui nilai $R$ Square (R) adalah 0,982, berarti hubungan keeratannya sangat kuat sekali antara rata-rata $\mathrm{pH}$ air limbah penambangan batubara dengan berbagai penambahan variasi dosis larut-an kapur $\left(\mathrm{Ca}(\mathrm{OH})_{2} 2 \%\right)$.

Menurut Sujianto (2009), nilai kekuatan hubungan (R) dapat dikelompokkan sebagai berikut :

0,00-0,20 = sangat lemah

$0,21-0,40=$ lemah

$0,41-0,70=$ kuat

$0,71-0,90=$ sangat kaut

$0,91-0,99$ = sangat kuat sekali

1 = hubungan keeratan sempurna

Untuk melihat perubahan rata-rata $\mathrm{pH}$ air limbah pada berbagai penambahan variasi dosis larutan kapur $\left(\mathrm{Ca}(\mathrm{OH})_{2} 2 \%\right)$ lebih jelas dapat dilihat pada gambar 1 . berikut.

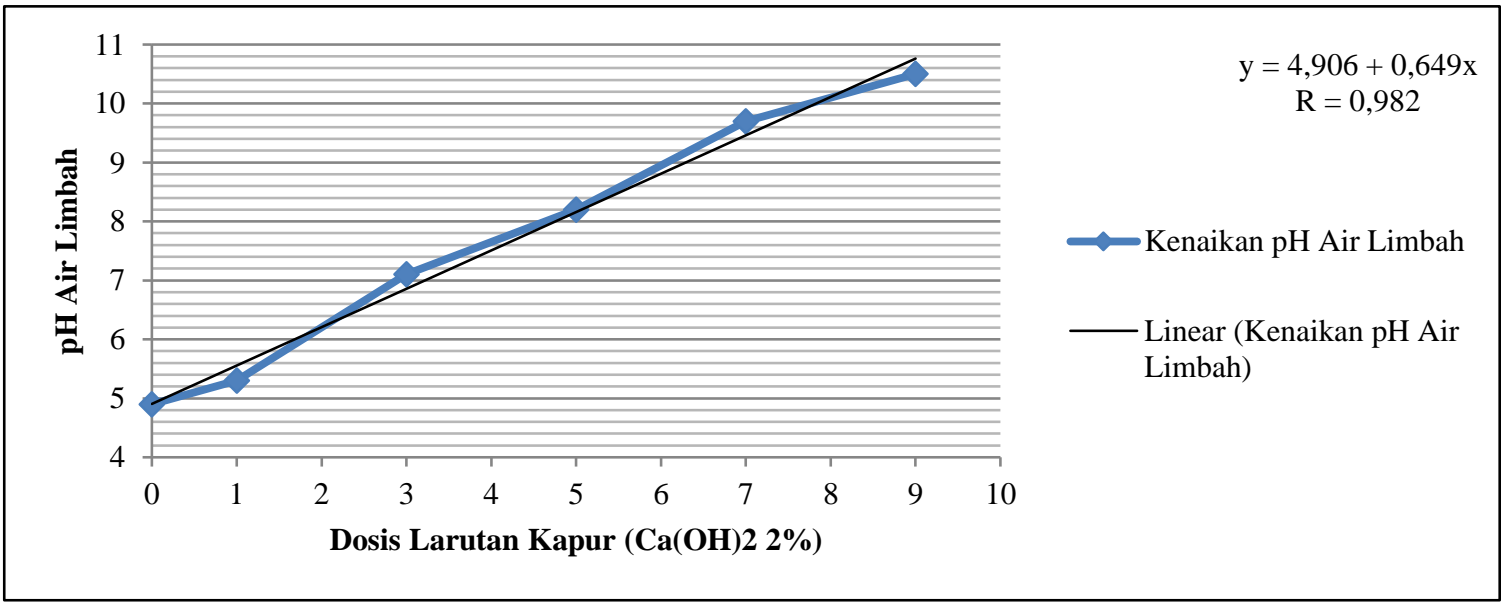

Gambar 1. Grafik Kenaikan pH Air Limbah Penambangan Batubara pada Berbagai Penambahan Varisai Dosis Larutan Kapur $\left(\mathrm{Ca}(\mathrm{OH})_{2} 2 \%\right)$

Berdasarkan grafik di atas dapat diketahui bahwa semakin banyak dosis larutan kapur $\left(\mathrm{Ca}(\mathrm{OH})_{2} 2 \%\right)$ yang ditambahkan ke dalam air limbah, maka $\mathrm{pH}$ air limbah tersebut akan semakin meningkat. Selain itu, juga diketahui dosis optimum larutan kapur $\left(\mathrm{Ca}(\mathrm{OH})_{2} 2 \%\right)$ untuk menjadikan pH air limbah memenuhi persyaratan (6-9), yaitu dengan menggunakan persamaan linier yang didapat $\mathrm{y}=$ $4,906+0,649 x$. Dosis larutan kapur 2\% yang diperlukan untuk menetralkan $\mathrm{pH}$ menjadi 6-9 dalam 1 liter air limbah adalah 1,7 mL sampai dengan 6,3 mL. Dosis optimum yang diperlukan untuk menetralkan pH menjadi 7 adalah $3,23 \mathrm{~mL}$ larutan kapur $\left(\mathrm{Ca}(\mathrm{OH})_{2} 2 \%\right)$ dalam 1 liter air limbah penambangan batubara.

Berdasarkan hasil penelitian laboratorium nilai rata-rata $\mathrm{pH}$ air limbah penambangan batubara awal (tanpa penambahan larutan kapur 2\%) adalah 
4,9, maka air limbah ini dapat dikatakan bersifat asam. Air limbah yang bersifat asam $(<6)$ dikarenakan pada saat penambangan batubara, dilakukan pengupasan lapisan-lapisan batuan supaya memudahkan pengambilan batubara yang berada di bawah beberapa lapisan batuan bahkan batubara itu terdapat pada salah satu dari lapisan batuan tersebut, pengupasan ini membuat lapisan batuan yang umumnya mengandung mineral sulfida terpapar ke udara sehingga mineral sulfida ini akan mengalami oksidasi karena adanya air dan oksigen. Mineral-mineral sulfida yang umum terdapat pada batuan diantaranya pirit $\left(\mathrm{FeS}_{2}\right)$ dan pirotit ( $\left.\mathrm{FeS}\right)$. Kandungan sulfur yang terdapat pada mineral tersebut akan dioksidasi oleh oksigen dan air. $\mathrm{FeS}_{2(\mathrm{~s})}+3 \mathrm{O}_{2(\mathrm{~g})}+2 \mathrm{H}_{2} \mathrm{O}_{(\mathrm{aq})} \rightarrow \mathrm{Fe}^{2+}{ }_{(\mathrm{aq})}+2$ $\mathrm{H}_{2} \mathrm{SO}_{4}{ }^{2-}(\mathrm{aq})$

Reaksi yang berlangsung merupakan reaksi pelapukan dari mineral sulfida disertai proses oksidasi. Sulfur dioksidasi menjadi asam sulfat dan besi fero dilepaskan. Dari reaksi ini dihasilkan dua mol keasaman (asam sulfat) dari setiap mol pirit yang teroksidasi. ${ }^{6}$

Berdasarkan Keputusan Menteri Negara Lingkungan Hidup Nomor 113 Tahun 2003, pH yang diperbolehkan adalah 6-9, sehingga $\mathrm{pH}$ air limbah penambangan batubara tidak memenuhi persyaratan. Oleh karena itu dilakukan proses netralisasi air limbah dengan menggunakan larutan kapur $\left(\mathrm{Ca}(\mathrm{OH})_{2} 2 \%\right)^{7}$

Larutan $\mathrm{Ca}(\mathrm{OH})_{2}$ disebut air kapur dan merupakan basa dengan kekuatan sedang. Larutan tersebut bereaksi hebat dengan berbagai asam. ${ }^{8}$

Menurut Zulfikar (2010) suatu asam bereaksi dengan suatu basa dalam reaksi penetralan untuk membentuk garam dan air. Proses reaksi penetralan air limbah penambangan batubara (asam) dengan menggunakan larutan kapur (basa). ${ }^{9}$

Reaksi : $\mathrm{H}_{2} \mathrm{SO}_{4}+\mathrm{Ca}(\mathrm{OH})_{2} \rightarrow \mathrm{CaSO}_{4}+2 \mathrm{H}_{2} \mathrm{O}$ asam basa garam air

Reaksi ion : $2 \mathrm{H}^{+} \mathrm{SO}_{4}{ }^{2-}+\mathrm{Ca}^{2+} 2 \mathrm{OH}^{-} \rightarrow \mathrm{Ca}^{2+}$ $\mathrm{SO}^{2-}+2 \mathrm{H}^{+} 2 \mathrm{OH}^{-}$

Dari reaksi kesetimbangan tersebut diketahui $\mathrm{H}_{2} \mathrm{SO}_{4}$ memiliki ion $\mathrm{H}^{+}$dan $\mathrm{Ca}(\mathrm{OH})_{2}$ memiliki ion $\mathrm{OH}$ - Reaksi tersebut akan menghasilkan garam dan air limbah penambangan batubara yang bersifat netral (7) jika penambahan larutan kapur dengan dosis yang tepat. Tetapi jika terlalu banyak larutan kapur yang ditambahkan maka akan menghasilkan air limbah yang bersifat basa ( $>9$ ) dan jika sebaliknya, membuat air limbah tetap bersifat asam $(<6)$.

Hasil pengukuran menggunakan larutan kapur $\left(\mathrm{Ca}(\mathrm{OH})_{2} 2 \%\right)$ dilakukan dengan penambahan berbagai variasi dosis, menunjukkan semakin banyak dosis larutan kapur $\left(\mathrm{Ca}(\mathrm{OH})_{2} 2 \%\right)$ yang ditambahkan ke dalam air limbah batu bara, maka $\mathrm{pH}$ akan semakin meningkat juga. Hal ini disebabkan larutan kapur yang bersifat basa memiliki ion $\mathrm{OH}^{-}$bereaksi dengan ion $\mathrm{H}^{+}$dari asam sulfat yang berasal dari air limbah penambangan batubara yang bersifat asam. Semakin banyaknya larutan kapur yang ditambahkan ke dalam air limbah maka semakin banyak ion $\mathrm{OH}^{-}$yang mengikat ion $\mathrm{H}^{+}$. Oleh karena itu semakin banyak larutan kapur $\left(\mathrm{Ca}(\mathrm{OH})_{2} 2 \%\right)$ maka akan meningkatkan pH air limbah penambangan batubara. Pada saat penambahan larutan kapur yang tepat akan meningkatkan $\mathrm{pH}$ air limbah menjadi netral.

Hasil uji beda menunjukkan ada perbedaan perubahan rata-rata $\mathrm{pH}$ air limbah pada berbagai penambahan variasi dosis larutan kapur $\left(\mathrm{Ca}(\mathrm{OH})_{2} 2 \%\right)$, Hal ini karena larutan kapur yang ditambahkan pada air limbah mempunyai dosis berbeda-beda sehingga ion $\mathrm{OH}^{-}$yang ada pada air limbah itu juga berbeda, maka menyebabkan $\mathrm{pH}$ air limbah pada setiap penambahan masing-masing variasi dosis larutan kapur $\left(\mathrm{Ca}(\mathrm{OH})_{2} 2 \%\right)$ juga berbeda-beda.

Hasil uji Korelasi tersebut nilai dari Sig. (2-tailed), nilainya adalah 0,000 lebih kecil dari $\alpha=0,05$, sehingga dapat dikatakan bahwa ada hubungan antara rata-rata $\mathrm{pH}$ air limbah penambangan batubara pada berbagai penambahan variasi dosis larutan kapur $\left(\mathrm{Ca}(\mathrm{OH})_{2} 2 \%\right)$. Karena ada hubungan, maka dapat dilanjutkan dengan uji Regresi linier untuk mendapatkan model persamaan linier.

Hasil dari uji Regresi linier didapatkan persamaan linier $y=4,906+0,649 x$ dengan nilai $\mathrm{R}=0,982$ (termasuk dalam nilai kekuatan 0,91-0,99), berarti hubung- 
an keeratannya sangat kuat sekali antara rata-rata $\mathrm{pH}$ air limbah penambangan batubara dengan berbagai penambahan variasi dosis larutan kapur $\left(\mathrm{Ca}(\mathrm{OH})_{2} 2 \%\right)$.

Persamaan linier $y=4,906+0,649 x$ dengan konstanta sebesar 4,906 menyatakan bahwa tanpa penambahan dosis larutan kapur 2\%, maka $\mathrm{pH}$ air limbah adalah 4,906. Sedangkan koefisien regresi sebesar 0,649 menyatakan bahwa setiap penambahan $1 \mathrm{ml}$ larutan kapur 2\% pada 1 liter air limbah akan menaikkan $\mathrm{pH}$ air limbah sebesar 0,649.

Berdasarkan perhitungan menggunakan persamaan regresi linier tersebut didapatkan dosis larutan kapur 2\% yang diperlukan untuk menetralkan $\mathrm{pH}$ menjadi 6-9 dalam 1 liter air limbah penambangan batubara adalah 1,7 mL sampai dengan 6,3 $\mathrm{mL}$. Dosis optimum yang diperlukan untuk menetralkan $\mathrm{pH}$ menjadi 7 adalah 3,23 mL larutan kapur $\left(\mathrm{Ca}(\mathrm{OH})_{2}\right.$ 2\%) dalam 1 liter air limbah penambangan batubara. Dibandingkan dengan Keputusan Menteri Negara Lingkungan Hidup Nomor 113 Tahun 2003 tentang Baku Mutu Air Limbah Bagi Usaha dan atau Kegiatan Pertambangan Batubara, $\mathrm{pH}$ yang diperbolehkan adalah 6-9, sehingga dengan menambahkan dosis larutan kapur $\left(\mathrm{Ca}(\mathrm{OH})_{2} 2 \%\right)$ tersebut dapat dikatakan air limbah penambangan batubara memenuhi persyaratan dari segi parameter $\mathrm{pH}$.

\section{KESIMPULAN DAN SARAN}

$\mathrm{pH}$ awal (sebelum perlakuan) air limbah penambangan batubara adalah 4,9. Sedangkan $\mathrm{pH}$ akhir (sesudah perlakuan) air limbah penambangan batubara adalah 7,1. Dosis optimum larutan kapur dalam menetralisasi $\mathrm{pH}$ air limbah penambangan batubara adalah $3,23 \mathrm{~mL}$ larutan kapur $\left(\mathrm{Ca}(\mathrm{OH})_{2} 2 \%\right)$ didalam 1 liter air limbah batubara untuk menetralkan pH menjadi 7.

Larutan kapur $\left(\mathrm{Ca}(\mathrm{OH})_{2} 2 \%\right)$ dapat diaplikasikan dengan dosis optimum yang didapat untuk menetralkan pH air limbah penambangan batubara. Gunakan alat dosing pump (alat khusus untuk menginjeksi larutan), agar dosis larutan kapur yang ditambahkan lebih tepat lebih mudah. pemeriksaan kualitas air limbah secara rutin dilakukan minimal 1 bulan sekali.

\section{DAFTAR PUSTAKA}

1. Asthari, Ratih. 2008. Pertambangan Batubara: Pro dan Kontra. http://majarimagazine.com/2008/06 Lpertambangan-batubara-pro-dankontra/. Diakses pada tanggal 4 Januari 2012.

2. Kementrian Energi dan Sumber Daya Alam. 2008. Statistik Batubara Indonesia.

http://www.esdm.go.id/download/St atistik Batubara Indonesia.pdf.

Diakses pada tanggal 10 Januari 2012

3. Putra, Rengga Avrizta. 2011. Lingkungan Hidup.

http://uwityangyoyo.wordpress.com. Diakses pada tanggal 5 Januari 2012.

4. Effendi, Hefni. Telaah Kualitas Air bagi Pengelolaan Sumber Daya dan Lingkungan Perairan. Yogyakarta: Kanisius. 2003.

5. Dinas Pertambangan dan Energi. Laporan Produksi Batubara (IUP) di Provinsi Kalimantan Selatan Tahun 2006-2011. Banjarbaru. 2011.

6. Pisco, Mario Lee. Laporan Kerja Praktek, Penanggulangan Air Asam Tambang dengan Pengapuran Selama 24 Jam terus menerus dengan Active Treatment pada PT. Tambang Batubara Bukit Asam. 2005.

7. Menteri Lingkungan Hidup. Keputusan Menteri Negara Lingkungan Hidup Nomor 113 Tahun 2003 Tentang Baku Mutu Air Limbah Bagi Usaha dan atau Kegiatan Pertambangan Batubara. Jakarta. 2003.

8. Ulfatmi, Maulida. Pengaruh Penambahan Kapur terhadap Perubahan $\mathrm{pH}$, Kekeruhan dan Total Padatan Terlarut pada Air Baku di Water Treatment Plant (WTP) di PT.Coca-Cola Bottling Indonesia Unit Medan. Sumatera Utara: Fakultas FMIPA Universitas Sumatera Utara. 2010.

9. Zulfikar. 2010. Reaksi Netralisasi. http://www.chem-is-try.org. Diakses pada tanggal 5 Januari 2012 